\title{
PARENTAL INVOLVEMENT IN HOME VISITATION: ITS RELATION TO STUDENTS PERSONAL DEVELOPMENT AMIDST THE PANDEMIC
}

\author{
Emily Christine O. Mañosca \\ Faculty, Paaralang Sekundarya ng Lucban Integrated School
}

Article DOI: https://doi.org/10.36713/epra7392 DOI No: 10.36713/epra7392

\begin{abstract}
This study was conducted to determine the Parental Involvement in Home Visitation: Its Relation to Students' Personal Development Amidst the Pandemic. Specifically, it sought to answer the following questions: What is the level of parental involvement in-home visitation in terms of parental support and parenting style? What is the level of student personal development amidst the Pandemic in terms of emotion, mental and social? Is there a significant relationship between parental involvement in home visitation its relation to student personal development amidst the Pandemic?

The research design used in this study was descriptive method of research because it answers basic questions about what is happening in a defined population and it utilized quantitative approach in gathering necessary data from the respondents.

The respondents were composed of Grade 7 students of Paaralang Sekundarya ng Lucban Integrated School, Lucban District, Division of Quezon. The Student were sought to answer the self-made checklist questionnaire prepared by the researcher. Mean, Standard Deviation and Correlation Analysis were applied as statistical test to achieve the objectives. The population of the study was 559 Grade 7 Students; random sampling technique was employed in selecting eighty (80) students from the 11 sections of Grade 7, (7) students for every sections. The result showed a moderate relationship between parental involvement in-home visitation through parents' support $(r=0.565, p=0.000)$ and parenting style $(r=0.577, p=0.000)$ with student emotional development. Such a relationship Is found highly significant as manifested by the probability values of 0.000 , which are both lower at 0.01 significance level, there is a moderate relationship between parental support in-home visitation through parent support $(r=0.515, p=0.000)$ and parenting style $(r=0.587, p=0.000)$ with student mental development. Such a relationship is still significant as manifested by the probability values of 0.000 which are both lower at the 0.01 significance level, weak relationship between parental support in-home visitation through parent support $(r=0.394, p=0.000)$ and parenting style $(r=0.379, p=0.001)$ with student social development. Such a relationship is still significant as manifested by the probability values of 0.000 which are both lower at the 0.01 significance level. It means there was a significant relation to student personal development between parental involvement in home visitation amidst the pandemic.

Based on the findings of the study, it is concluded that the student personal development has a relation between parental involvement in home visitation amidst the pandemic. It is crucial that the parents actively share responsibilities in the pandemic because it positively impacts the students' academic achievements, especially the child's behavior. The researcher highly recommends that: teachers' may conduct home visitation as a tool to check on the well-being and personal development of the students when the general level of the community quarantine allows it; parents may communicate with the teacher through different online messaging platforms or through text messaging during times when home visitation is not allowed by the level of the community quarantine; students may have established good communication with their teachers, especially those encountering difficulties adjusting to the new normal education system, and may use different platforms of communication; home Visitation may be conducted depending on COVID Risk Severity Classification and compliance with minimum health standards. Always observe the latest updates and guidelines of IATF in conducting home visitation; future researchers are encouraged to do further studies emphasizing the variables in the present studies.
\end{abstract}

\section{INTRODUCTION}

According to the UN Declaration on the Rights of the Child (1959) in Principle 7, the child is entitled to receive a quality education, free and compulsory, at least in the elementary stages. All children have a right to access free, quality education to develop their abilities, individual judgment, and sense of moral and social responsibility to become effective members of society. The responsibility of the parents is to guide the child in his education, support the child financially, emotionally, mentally, and physically. Parents should explain the 
importance of education so that the child gains interest in his education.

In the last few months, the country is facing an economic crisis due to the Pandemic (Covid-19). Many people face different problems, and the most affected in this situation is the children's education. The Department of Education finds ways to continue education amidst the Pandemic and the learning modality in the New Normal is Modular Distance Learning (MDL). In modular distance learning, parents are the partners of teachers in education; they are the home facilitator. The primary role of the parents in modular distance learning is to establish a connection and guide the child properly. Parents and children encounter different problems such as difficulty answering the assigned task in the module, difficulty understanding the topics in the modules, difficulty submitting modules on time, and other students lacking the motivation to accomplish different tasks.

As per DepEd Order no. 032 s. 2020 Section I. Rationale No. V. Procedures E. Health and Safety Protocols, Secondary School Teachers abiding by the required health and safety protocols may continuously include home visitation as part of the duties. Parents are recommended to actively participate in the home visitation to help the learners to adjust to the new learning modalities.

Based on page 8 of the guidelines for areas placed under general community quarantine by the IATF No. 11a, the Basic Education Learning Continuity Plan of the Department of Education is adopted. Home Visitation may be conducted depending on COVID Risk Severity Classification and compliance with minimum health standards. Using home visitation, teachers shall observe and understand the child's behavior and the parents as well. In-home visitation teachers gather more information regarding the family background and status of the learner, and it is an excellent way to understand challenges faced by the learner through home visitation.

This study was conducted to give insight to parents and students about the importance of parental involvement in home visitation: its relation to student personal development amidst the Pandemic, and to attempt to offer a solution.

\section{RESEARCH METHODOLOGY}

This study employed quantitative method research design in gathering necessary data. Descriptive-correlation design because correlation design is a statistical technique that can show whether and how strongly pairs of variables are related McCombes (2019). Descriptive research aims to accurately and systematically describe a population, situation, or phenomenon, and it includes a purpose and a question. It is the most basic research design; it answers basic questions about what is happening in a defined population.

The respondents of the study consisted of Grade 7 students in Paaralang Sekundarya ng Lucban Integrated School, Lucban, Quezon. The respondents of this study were composed of 80 selected grade 7 students.

The researcher used simple random sampling to selected Grade-7 Students in Paaralang Sekundarya ng Lucban Integrated School. in getting eighty (80) respondent from the 11 sections of grade7 , seven (7) from the section of einstein, seven (7) from the section of wisdom, seven (7) from the section of love, seven (7) from the section of hope, seven (7) from the section of faith, seven (7) from the section of honesty, seven (7) from the section of peace, seven (7) from the section of humility, seven (7) from the section of courage, seven (7) from the section of courteous, seven (7) from the section of charity, three (3) from the section of ohsp. Equal chances were given to them so that the data was not biased and was reliable.

The main instrument used in the study was a questionnaire formulated by the researcher. The questionnaire is composed of 2 sets. Each set contains seven items. The questions consisted of statements used to determine parental involvement in home visitation: its relation to student personal development amidst the Pandemic The questionnaire was the primary tool to identify the Parent Involvement in Home Visitation: Its Relation to Student Personal Development Amidst the Pandemic. It is an efficient way to obtain information from some students. The Likert Scale was used for the interpretation of the values of the gathered data. After collecting the necessary data, descriptive and inferential statistics were administered. The data summary gathered from the respondents with the use of tables and text and to explain what the tables were showing. The quantitative results cover the interpretation and explanation of quantitative result and determining the relationship between independent and dependent variable. 


\section{STATISTICAL TREATMENT}

The following statistical tools were used in treating the data gathered by the researcher.

\begin{tabular}{|c|l|}
\hline Statement of the Problem & \multicolumn{1}{|c|}{ Statistical Treatment } \\
\hline $1 . \quad \begin{array}{l}\text { What is the level of Parental Involvement in Home Visitation } \\
\text { in terms of: Parental Support and Parenting Style? }\end{array}$ & $\begin{array}{l}\text { Weighted Mean and Standard } \\
\text { Deviation }\end{array}$ \\
\hline 2. $\begin{array}{l}\text { What is the level of Student Personal Development amidst the } \\
\text { Pandemic in terms of: Emotion, Mental and Social? }\end{array}$ & $\begin{array}{l}\text { Weighted Mean and Standard } \\
\text { Deviation }\end{array}$ \\
\hline $\begin{array}{l}\text { 3. Is there a significant relationship between parental } \\
\text { involvement in home visitation its relation to student personal } \\
\text { development amidst the Pandemic? }\end{array}$ & Correlation analysis \\
\hline
\end{tabular}

\section{RESULTS AND DISCUSSIONS}

Table 1. Level of Parental Involvement in Home Visitation in terms of Parental Support

\begin{tabular}{|c|c|c|c|}
\hline Indicative Statement & Mean & SD & Verbal Interpretation \\
\hline 1. Thru home visitation my parent participates in school. & 4.46 & 0.64 & Very High \\
\hline $\begin{array}{l}\text { 2. By means of home visitation, my parent motivates me to do } \\
\text { well. }\end{array}$ & 4.49 & 0.62 & Very High \\
\hline $\begin{array}{l}\text { 3. Since the home visitation is conducted, my parents are } \\
\text { willing to support in different problems I encounter. }\end{array}$ & 4.33 & 0.63 & Very High \\
\hline $\begin{array}{l}\text { 4. My parents understand the difficulty I am experiencing in the } \\
\text { learning process, but by means of conducting home visitation, } \\
\text { my parents are willing to guide me. }\end{array}$ & 4.45 & 0.67 & Very High \\
\hline $\begin{array}{l}\text { 5. Thru home visitation, my parents give feedback about my } \\
\text { performance. }\end{array}$ & 4.40 & 0.63 & Very High \\
\hline $\begin{array}{l}\text { 6. In conducting home visitation, my parents listen attentively } \\
\text { when discussing my performance and willing to help me. }\end{array}$ & 4.35 & 0.68 & Very High \\
\hline $\begin{array}{l}\text { 7. By means of home visitation, my parent is willing to have } \\
\text { teamwork and collaboration regarding my performance. }\end{array}$ & 4.30 & 0.68 & Very High \\
\hline Overall Mean & 4.40 & & Very High \\
\hline
\end{tabular}

Legend:

$$
\begin{array}{cl}
4.20-5.00 & \text { Very High } \\
3.40-4.19 & \text { High } \\
2.60-3.39 & \text { Moderate } \\
1.80-2.59 & \text { Low } \\
1.00-1.79 & \text { Very Low }
\end{array}
$$

It could be gleaned from the table the level of parental involvement in-home visitation in terms of parental support. Results show that by home visitation, parents motivates to do well describes as very high $(M=4.49, S D=0.62)$; employing home visitation parents participates in school it was interpreted as very high $(M=4.46, S D=0.64)$ through parental involvement in home visitation the parents able to participates in the school-related activities; parents understand the difficulty being experienced in the learning process is very high $(M=4.45, S D=0.67)$. Likewise the respondents, very highly agree thru home visitation, parents give feedback about the performance of the learner $(M=4.40, S D=0.63)$, the parents listen attentively when discussing their performance and willingness to help them regarding their performance and was interpreted as very high $(M=4.35, S D=0.68)$; the willingness of parents to support in different problems encounter is very high needed $(M=4.33, \quad S D=0.63) ; \quad$ as parents, the willingness to have teamwork and collaboration regarding school performance was very high essential $(M=4.30, S D=0.68)$ by this the learners are motivated to do well.

The overall mean of 4.40 further shows that parental involvement in-home visitation as to their support is very high. Small standard deviation values in almost all indicators show that students have almost the same or common perception concerning parents' support. The parental support in-home visitation establishes communication between the teacher, parents, and the child to see the positive outcome on the student performance.

The findings were supported by Untevero (2013) as cited by Cabriga (2014), parental support deals with the participation of parents in school and even in the life of their child. Through parental support, the child motivates to accomplish different 
tasks. Also, through home visitation, parents become aware of the performance of the children in school. After the home visitation, parents are eventually supporting their child. Parental support has an impact on the performance of the child. Through parental support in-home visitation, the children develop a lifelong love of learning.

According to Khan et al. (2011), parental support has a positive impact on children's education. It also creates self-confidence for the child. Using home visitation, parents become responsive to the child's development; parental support is the best way to build a strong relationship between parents, children, and teachers. This strong relationship can help students in developing self-confidence that can lead to becoming better people. Parental support is the best way to create a positive environment for every child.

It is construed that parental support in home visitation positively impacts the child's performance in school, like increasing academic achievement, improving behavior, and impacting a child's personality. Through home visits, it can establish better communication between the parents, child, and students, and it can also motivate parents to get involved in the child's performance in school. Parents also try their best to become more involved in the child's development, especially in academic performance in school that parental support gives positive outcomes in the child.

Table 2. Level of Parental Involvement in Home Visitation in terms of Parenting Style

\begin{tabular}{|l|c|c|c|}
\hline \multicolumn{1}{|c|}{ Indicative Statement } & Mean & SD & Verbal Interpretation \\
\hline $\begin{array}{l}\text { 1. Thru home visitation, my parents become responsive to } \\
\text { my needs. }\end{array}$ & 4.38 & 0.72 & Very High \\
\hline $\begin{array}{l}\text { 2. By means of home visitation, my parents explain to me } \\
\text { about their expectations. }\end{array}$ & 4.21 & 0.67 & Very High \\
\hline $\begin{array}{l}\text { 3. In conducting home visitation, my parents provide } \\
\text { comfort when I am upset. }\end{array}$ & 4.28 & 0.73 & Very High \\
\hline $\begin{array}{l}\text { 4. Thru home visitation, my parents encouraged me to talk } \\
\text { about my thoughts and feelings }\end{array}$ & 4.29 & 0.66 & Very High \\
\hline $\begin{array}{l}\text { 5. Using home visitation, I am aware that my parent guides } \\
\text { me when I make an important decision. }\end{array}$ & 4.41 & 0.69 & Very High \\
\hline $\begin{array}{l}\text { 6. Thru home visitation, my parents encouraged me to } \\
\text { explain my views and opinions. }\end{array}$ & 4.29 & 0.66 & Very High \\
\hline 7. Utilizing home visitation, my parents give compliments. & 4.21 & 0.69 & Very High High \\
\hline Overall Mean & $\mathbf{4 . 2 9}$ & & . \\
\hline
\end{tabular}

Legend:

$\begin{array}{ll}4.20-5.00 & \text { Very High } \\ 3.40-4.19 & \text { High } \\ 2.60-3.39 & \text { Moderate } \\ 1.80-2.59 & \text { Low } \\ 1.00-1.79 & \text { Very Low }\end{array}$

In terms of Parenting style, the respondents perceived very highly needs that thru home visitation, the parents will guide the child in making an important decision $(M=4.41, S D=0.69)$; parents are very highly become responsive in their needs $(M=$ 4.38, $S D=0.72$ ); parents encourage the child to share thoughts and feelings $(M=4.29, S D=0.66)$ with described as very high; through the home, visitation parents is very highly encouraged the child to explain their views and opinions $(M=4.29, S D=0.66)$; in conducting home visitation the parent is very highly needed to give and provide comfort when the students are upset $(M=4.28, S D=0.73)$, it is very highly needed that parents explain their views and opinions $(M=4.21, S D=0.67)$; by means of home, visitation parents is very highly give compliments $(M=4.21, S D=0.69)$.
The overall mean of 4.29 indicates that parental involvement in-home visitation regarding their parenting style is very high. Small standard deviation values in almost all indicators show that students have almost the same or common perception with regard to parenting style. Thus, parenting style can improve the behavior of the child to become an independent individual.

The findings were supported by Abesha (2012) as cited by Alison (n.d.). The parenting style has a positive outcome for the children when it comes to school performance, and it is also visible in the child actors on how the children interact with other people. Parenting style is important because it supports healthy growth and development. The way that the parents interact with the children and how the 
parents discipline the child will impact the rest of the children's lives.

In addition, as cited by Arceta (2016), they consistently keep an eye on, manage, and use noninflicting methods or discipline when rules are violated. Through parenting style, parent care, and protecting the child from harm, parent enforced boundaries for children to be guided through their actions.
To sum it up, parents influence influences the behavior of their children through their specific practices. Parenting style builds a healthy growth and development of children also it develops strong emotional bonds that can help the children to manage their feelings, behavior and can develop selfconfidence this self-confidence can help the children perform well in whatever task is given.

Table 3. Level of Student Personal Development in terms of Emotion amidst the Pandemic

\begin{tabular}{|c|c|c|c|}
\hline Indicative Statement & Mean & SD & Verbal Interpretation \\
\hline $\begin{array}{l}\text { 1. I understand what emotion I feel in the sudden change } \\
\text { of learning modality because of the pandemic. }\end{array}$ & 4.30 & 0.68 & Very High \\
\hline $\begin{array}{l}\text { 2. I understand that I encounter a financial crisis due to the } \\
\text { Covid-19 Pandemic that affects my academic } \\
\text { performance. }\end{array}$ & 4.18 & 0.71 & High \\
\hline $\begin{array}{l}\text { 3. Most of the time, I feel worn out because of many } \\
\text { activities to be accomplished. }\end{array}$ & 4.06 & 0.75 & High \\
\hline $\begin{array}{l}\text { 4. In times of the Covid- } 19 \text { Pandemic, my parents support } \\
\text { me in my performance in school. }\end{array}$ & 4.45 & 0.65 & Very High \\
\hline $\begin{array}{l}\text { 5. My parent guides me when the problem occurs because } \\
\text { of the difficulty in the learning process due to pandemic. }\end{array}$ & 4.34 & 0.69 & Very High \\
\hline $\begin{array}{l}\text { 6. I feel motivated when there is a difficult task to be } \\
\text { accomplished. }\end{array}$ & 4.18 & 0.76 & High \\
\hline $\begin{array}{l}\text { 7. I am aware of my emotions due to the New Normal } \\
\text { System of Education. }\end{array}$ & 4.21 & 0.72 & Very High \\
\hline Overall Mean & 4.24 & & Very High \\
\hline $\begin{array}{ll}\text { Legend: } & \\
4.20-5.00 & \text { VeryHigh } \\
3.40-4.19 & \text { High } \\
2.60-3.39 & \text { Moderate } \\
1.80-2.59 & \text { Low } \\
1.00-1.79 & \text { Very Low }\end{array}$ & & & \\
\hline
\end{tabular}

In terms of emotion, the respondents perceived very highly important in times of the covid19 pandemic they feel that parents support them in school performance $(M=4.45, S D=0.65)$. Parents guide their children when the problem occurs $(M=$ 4.34, $S D=0.69)$ described as very high. Likewise, students understand their emotions because of the sudden change of learning modality because of pandemic $(M=4.30, S D=0.68)$ described as very high. Due to new normal system of education student is very highly aware of their emotion $(M=4.21, S D=$ 0.72 ). The students understand that financial crisis encounters due to the covid-19 pandemic can affect the academic performance $(M=4.18, S D=0.71)$ describes as high. Students are highly motivated if they accomplish a difficult task $(M=4.18, S D=0.76)$ because they feel happy when they finish the task given to them. Students highly feel worn out because of lots of activities to be accomplished $(M=4.06$, $S D=0.75)$. In times of pandemic, students face difficulty.
The overall mean of 4.24 indicates that students' personal development regarding their emotional attributes is very high. Small standard deviation values in almost all indicators show that students have almost the same or common perception regarding their emotions. The emotional attributes affect the student's personal development, but with the proper guidance of their parent, they face different problems that they will encounter.

This was supported by the study of Teruel et al. (2020), who stated that students suggested feeling motivated because of the factors that will lessen the emotional effects in the stressful events due to the changes of environment, and the sudden covid-19 pandemic encountered. Covid-19 pandemic gives emotional consequences on the students because of the sudden change of learning modalities, but with the proper guidance of their parents in the new normal system of Education, they motivate their children to adopt the changes brought by the current situation to the covid-19 pandemic. 
The result was supported by the study of Pajarianto (2020). Academic stress caused by study at home during the pandemic Covid-19 can be outdone by maximizing student religiosity, teacher support, and parent support at home. The following supports gave by the teacher and parents can lessen the emotional stress to the student because they motivate to accomplish a different task that is given to them, even learning at home because of the current situation due to the covid-19 pandemic.

In conclusion, parents in this time of covid19 pandemic can help the child lessen emotional stress because of the current situation caused by the covid-19 pandemic. Parents should act as a source of strength for the child to lessen the effects of trauma and by helping each other to establish a safe and supportive environment for learning. Also, the teacher should develop differentiated instruction for the students in connecting the curriculum that suits their interests and providing them to showcase their knowledge and skills in different platforms that can demonstrate their learnings. The different instructional material will catch the student's attention, and the students will be able to accomplish the different tasks given to them because they quickly learn by having differentiated instructions made by the teachers. Despite the imposed situation because of the covid-19 pandemic, students must be aware of different challenges they encounter, and students show enthusiasm towards their learning.

Table 4. Level of Student Personal Development in terms of Mental amidst the pandemic.

\begin{tabular}{|c|c|c|c|}
\hline Indicative Statement & Mean & SD & Verbal Interpretation \\
\hline $\begin{array}{l}\text { 1. I can follow instructions while having difficulties in } \\
\text { the learning process due to the current situation. }\end{array}$ & 4.30 & 0.72 & Very High \\
\hline $\begin{array}{l}\text { 2. I learn to make my own decision regarding my } \\
\text { academic performance while learning at home because } \\
\text { of the pandemic. }\end{array}$ & 4.10 & 0.82 & High \\
\hline $\begin{array}{l}\text { 3. I can face any situation when the problem occurs } \\
\text { due to a pandemic. }\end{array}$ & 3.91 & 0.81 & High \\
\hline $\begin{array}{l}\text { 4. My parents help me to think of a solution to own } \\
\text { problems I encounter creatively. }\end{array}$ & 4.20 & 0.64 & Very High \\
\hline $\begin{array}{l}\text { 5. Due to the current situation, I know my } \\
\text { responsibility in whatever task is given to me. }\end{array}$ & 4.20 & 0.79 & Very High \\
\hline $\begin{array}{l}\text { 6. My parents help me to motivate myself to do things } \\
\text { well despite the current situation. }\end{array}$ & 4.46 & 0.67 & Very High \\
\hline $\begin{array}{l}\text { 7. Despite the pandemic, my parents set a goal to be } \\
\text { accomplished }\end{array}$ & 4.34 & 0.71 & Very High \\
\hline Overall Mean & 4.22 & & Very High \\
\hline $\begin{array}{cl}\text { Legend: } & \\
4.20-5.00 & \text { Very High } \\
3.40-4.19 & \text { High } \\
2.60-3.39 & \text { Moderate } \\
1.80-2.59 & \text { Low } \\
1.00-1.79 & \text { VeryLow }\end{array}$ & & & \\
\hline
\end{tabular}

In terms of mental attributes, parents help them motivates them to do things well, despite the current situation $(M=4.46, S D=0.67)$ describe as very high. Despite the pandemic, parents are very highly set goals for the children to accomplish a different task $(M=4.34, S D=0.71)$. Students follow instructions despite difficulties in the learning process due to the covid-19 pandemic ( $M=4.30, S D=$ 0.72) describes as very high. Parents help them to think for the solution for their own problems they encounter creatively $(M=4.20, S D=0.64)$ with a descriptive rating of very high. Because of the current situation, the student knows their responsibilities in the task given to them $(M=4.20, S D=0.79)$ describes as very high. Likewise, students are highly making their own decision regarding academic performance while learning at home because of pandemic $(M=$
4.10, $S D=0.82$ ). Meanwhile, they can face situations highly when a problem occurs due to a pandemic $(M=3.91, S D=0.81)$.

The overall mean of 4.22 indicates that students' personal development as to their mental attributes is very high. Small standard deviation values in almost all indicators show that students have almost the same or common perception regarding their mental attributes. The current situation brought by pandemics affects the student in making decisions with the guidance of their parents; they can manage to make their own decision.

This was supported by the study of Zhai et al. (2020) that the college student encounters challenges on mental health due to Covid-19. The government should seek urgent support for the challenges faced by the student; through this, 
students can adopt the changes they encounter due to pandemics.

The finding was supported by Liu et al. (2020) that the covid-19 pandemic has an impact on college students due to new learning modality in the new normal set-up, to lessen the mental stress of the students, parent, as well as teachers, promote different types of support to ensure the mental health of the students that can affect their personal development, but by means of home, visitation parents will be much aware in different challenge encounter by the student.

The statement above shows the mental attributes of the students due to the covid-19 pandemic student needs to adapt to changes in the New Normal System of Education.

Table 5. Level of Student Personal Development in terms of Social amidst the Pandemic

\begin{tabular}{|l|c|c|c|}
\hline \multicolumn{1}{|c|}{ Indicative Statement } & Mean & SD & $\begin{array}{c}\text { Verbal } \\
\text { Interpretation }\end{array}$ \\
\hline $\begin{array}{l}\text { 1. My parent encourages to get along with a variety of } \\
\text { people. }\end{array}$ & 4.03 & 0.86 & High \\
\hline $\begin{array}{l}\text { 2. Even in the current situation, my parents encouraged } \\
\text { me to share my thoughts and ideas clearly with others. }\end{array}$ & 4.18 & 0.69 & High \\
\hline $\begin{array}{l}\text { 3. Despite the pandemic, my parents help me to pay close } \\
\text { attention when someone is talking to me, especially when } \\
\text { it comes to school matters. }\end{array}$ & 4.29 & 0.75 & Very High \\
\hline $\begin{array}{l}\text { 4. In the current situation, peer and my family are an } \\
\text { essential factor to improve my performance. }\end{array}$ & 4.44 & 0.69 & Very High \\
\hline $\begin{array}{l}\text { 5. Despite pandemic, I can read between lines in every } \\
\text { situation I am facing. }\end{array}$ & 4.29 & 0.66 & Very High \\
\hline 6. I can learn easily with peers. & 3.95 & 0.90 & High \\
\hline $\begin{array}{l}\text { 7. Even in current situation my parent encourages me to } \\
\text { have a collaboration with my peers thru online } \\
\text { communications. }\end{array}$ & 4.10 & 0.72 & \\
\hline Overall Mean & & & \\
\hline Legend: High \\
$4.20-5.00 \quad$ Very High
\end{tabular}

In terms of social attributes, the peer and family are the important factor to improve the performance in school $(M=4.44, S D=0.69)$ described as very high; the parent need to help their children to pay close attention when someone is talking, especially in school matters $(M=4.29, S D=0.75)$ described as very high; students can read between two lines in every situation they are facing $(M=4.29, S D=0.66)$ with a descriptive rating of very high; they highly encourage their child to share their thoughts and ideas clearly with others $(M=4.18, S D=0.69)$; even in the current situation parents highly encourage their children to have a collaboration with their peers thru online communication $(M=4.10, S D=0.72)$; parents highly encourage to get along with the variety of people $(M=4.03, S D=0.86)$; students highly learn easily with peers $(M=3.95, S D=0.72)$.

The overall mean of 4.18 indicates that students' personal development as to their social attributes is high. Small standard deviation values in almost all indicators show that students have almost the same or common perception with regard to their social attributes. This current situation because of the covid-19 pandemic affects the socialization of the students with their peers, but there are lots of different flatforms on how they can easily get along with, aside from this, peer and family are important factors to the personal development of the child.

As backed up by the study of Arnado et al. (2020), close family ties and peers play an important role in their mental development. This means that family and peers serve as an inspiration of the students that can help students boost their confidence in making their own decisions and facing different challenges they encounter because of the current situation due to the covid-19 pandemic.

Furthermore, Kazerooni et al., (2020) stated that in the university students in Iran developed an online peer platform, $71 \%$. This new normal set-up help student to lessen the challenges they are facing. Peers can help the student to motivate them, especially in their academic performance.

To sum it up, peer relationship is an essential factor in student personal development 
amidst pandemic, using different platforms can help

students interact apart from academic learning.

\section{Relationship between Parental Involvement in Home Visitation and Student Personal Development in terms of Emotional Attributes.}

Table 6. Significant Relationship between Parental Involvement in Home Visitation and Student Personal Development in terms of Emotional Attributes

\begin{tabular}{|l|c|c|c|c|}
\hline \multicolumn{1}{|c|}{ Indicator } & $\mathbf{r}$ & Interpretation & $\boldsymbol{p}$ & Analysis \\
\hline Parental Support & 0.565 & Moderate & 0.000 & Significant \\
\hline Parenting Style & 0.577 & Moderate & 0.000 & Significant \\
\hline
\end{tabular}

Adjusted $R^{2}=0.3751$

The study shows a moderate relationship between parental involvement in-home visitation through parents' support $(r=0.565, p=0.000)$ and parenting style $(r=0.577, p=0.000)$ with student emotional development. Such a relationship Is found highly significant as manifested by the probability values of 0.000 , which are both lower at 0.01 significance level. Subjected to simple regression analysis to determine the adjusted $\mathrm{R}^{2}$, as both indicators were found highly significant, it shows that $37.51 \%$ of the student's emotional development variance is explained by the variance of the parental involvement in home visitation parental support and style.

Borup et al. (2015) stated that there is emotional feedback in times of covid-19 pandemic. The guidance of the parents in times of covid-19 pandemic plays an important role in easing the emotional stress of the students. It shows that it has a positive effect on the child's academic performance in school.
Carbonel, Banggaan \& Agbisit supported the result (2013) the emotional behavior of the child affects the academic performance of the students but with the support of their parents, especially in the school academic progress of their child. This shows that being academically aware of the parents in the child's performance in school can help the student motivation to do well.

From the above statement, the parents play an important role in child emotional development; the parents should continuously guide and support their child to whatever decisions they will make, by the proper guidance of the parents, the child can express and manage feelings and parental involvement in home visitation influences the emotional development because child motivates to face different challenges they encounter and the achievement of the child is visible in the academic performance of the child while in the new normal system of education.

Table 7. Significant Relationship between Parental Involvement in Home Visitation and Student Personal Development in terms of Mental Attributes.

\begin{tabular}{|l|c|c|c|c|}
\hline \multicolumn{1}{|c|}{ Indicator } & $\mathrm{r}$ & Interpretation & $p$ & Analysis \\
\hline Parental Support & 0.515 & Moderate & 0.000 & Significant \\
\hline Parenting Style & 0.587 & Moderate & 0.000 & Significant \\
\hline
\end{tabular}

Adjusted $R^{2}=0.3553$

Results show that there is a moderate relationship between parental support in-home visitation through parent support $(r=0.515, p=0.000)$ and parenting style ( $r=0.587, p=0.000)$ with student mental development. Such a relationship is still significant as manifested by the probability values of 0.000 which are both lower at the 0.01 significance level. Subjected to simple regression analysis to determine the adjusted $\mathrm{R}^{2}$, as both indicators were found highly significant, it shows that $35.53 \%$ of the student's mental development variance is explained by the variance of the parental involvement in home visitation parental support and style.

This was supported by Minn et al. (2020) mental development of a person has the biggest effect, especially in the changes of the learning modality in the new normal system of Education, but in spite of parental support in-home visitation, students learn to accept the changes and continue to improve their performance in school.

To sum up, parental involvement in home visitation plays a vital role in the continuous improvement of the students. Parental support and parenting style the students come actively engage in solving their problems in these current situations. Through parental involvement, the students assume an independent role in the learning process, and they are continuously responsible. 
Table 8. Significant Relationship between Parental Involvement in Home Visitation and Student Personal Development in terms of Social Attributes

\begin{tabular}{|l|c|c|c|c|}
\hline \multicolumn{1}{|c|}{ Indicator } & $\mathrm{r}$ & Interpretation & $p$ & Analysis \\
\hline Parental Support & 0.394 & Weak & 0.000 & Significant \\
\hline Parenting Style & 0.379 & Weak & 0.001 & Significant \\
\hline
\end{tabular}

Adjusted $R^{2}=0.1582$

The study shows a weak relationship between parental support in-home visitation through parent support $(r=0.394, p=0.000)$ and parenting style ( $r=0.379, p=0.001)$ with student social development. Such a relationship is still significant as manifested by the probability values of 0.000 which are both lower at the 0.01 significance level. Subjected to simple regression analysis to determine the adjusted $\mathrm{R}^{2}$, as both indicators were found highly significant, it shows that $15.82 \%$ of the student's social development variance is explained by the variance of the parental involvement in home visitation parental support and style.

Base on the study of Chen et al. (2020), peer support can help to lessen anxiety and stress during a pandemic; with the proper guidance and support of their parents in the current situation, students can ease the stress and anxiety in times of pandemic.

The findings also supported by Andrews et al. (2020) that the proper supervision and support of the parents using different platforms impact online support with their peers and could help the students gain attention in the learning process.

To sum it up, parental involvement and parenting style in-home visitation impact the social development of the child; with this, they can easily learn to gain attention and motivate them to do well. Therefore, the null hypothesis was rejected.

\section{CONCLUSION}

Based on the data gathered, it shows that the null hypothesis stating that "There is no significant relationship between parental involvement in-home visitation and its relation to student personal development amidst the pandemic was rejected. There was a significant relation to student personal development between parental involvement in home visitation amidst the pandemic. It is crucial that the parents actively share responsibilities in the pandemic because it positively impacts the students' academic achievements, especially the child's behavior.

\section{RECOMMENDATION}

Based on the findings and conclusions of the study, the following recommendations are hereby given:

1. Teachers' may conduct home visitation as a tool to check on the well-being and personal development of the students when the general level of the community quarantine allows it.

2. Parents may communicate with the teacher through different online messaging platforms or through text messaging during times when home visitation is not allowed by the level of the community quarantine.

3. Students may have established good communication with their teachers, especially those encountering difficulties adjusting to the new normal education system and may use different platforms of communication.

4. Home Visitation may be conducted depending on COVID Risk Severity Classification and compliance with minimum health standards. Always observe the latest updates and guidelines of IATF in conducting home visitation.

5. Future Researchers are encouraged to do further studies emphasizing the variables in the present studies.

\section{REFERENCES}

1. Abesha (2012) "Reconceptualization of the authoritarian parenting style and paternal control: Some initialitems." Retrieved November 13, 2016, from

https://orders.edrs.com/members/sp.cfm?AN=ED 403015

2. Alison, A. (2016) Parenting Styles and DecisionMaking of Grade VI Pupils: Correlation.

3. Andrade, David (2015). The Importance of Communication in Education. Retrieve from Online on 15/08/2015 http://www.techlearning.com/blogentry/8716

4. Andrews, J. L., Foulkes, L., \& Blakemore, S.-J. (2020). Peer influence in adolescence: Publichealth implications for COVID-19. Trends in Cognitive Sciences, 24(8), 585-587. https://doi.org/10.1016/j.tics.2020.05.001.

5. Aristovnik Aleksander, Damijana Kerži č, Dejan Ravšelj, Nina Tomaževi 'c and Lan Umek (2020), Impacts of the COVID-19 Pandemic on Life of Higher Education Students: A Global Perspective https://doi.org/10.3390/su12208438 13 October 2020

6. Arceta, M. (2016) Parenting Styles and Its Influence on the Socio-Emotional Aspects of Intermediate Pupils.

7. Arnado, Jeric Anthony S., Rogelio P. Bayod (2020). Help Seeking Behavior of Young Filipinos Amidst Pandemic: The Case of Cor Jesu College Students 
8. Baumind, D. "Current Patterns of Paternal Authority." DEVELOPMENTAL PSYCHOLOGY MONOGRAPHPS 4 (2010):1- 103. https://hbzqezpst6kr/baumrind-parentingstyle/retrieved from January 2016.

9. Bello, A., Pinson, M., \& Tuliao, A. P. (2013, October). The relationship of loss of face, stigma, and problem severity, on attitudes and intent to seek face-to-face or online counseling. Paper presented at the 50th Psychological Association of the Philippines and the 4th ASEAN Regional Union of Psychologists joint convention, Miriam College, Quezon

10. Borup, J., West, R. E., \& Thomas, R. (2015). The impact of text versus video communication on instructor feedback in blended courses. Education Technology Research and Development, 63, 161-184.

11. Bukowski, W. M., Buhrmester, D., \& Underwood, M. K. (2011). Peer relations as a developmental context. In M. K. Underwood \& L. H. Rosen (Eds.), Social development (pp. 153-179). New York, NY: Guilford

12. Burgess, S., \& Sievertsen, H. H. (2020). Schools, Skills, and Learning: The Impact of COVID-19 on Education. https://voxeu.org/article/impactcovid-19-education

13. Carbonell. G. L., Banggawan M. L., \& Agbisit, I. (2013). Parent's role in enhancing the academic performance of students in the study of mathematics in Tabuk City, Philippines. International Journal of Advanced Research in Management and Social Sciences, 2(8), 22786236.

14. Cheng, P., Xia, G., Pang, P., Wu, B., Jiang, W., Li, Y.-T., Wang, M., Ling, Q., Chang, X., Wang, J., Dai, X., Lin, X., Bi, X. (2020). COVID-19 epidemic peer support and crisis intervention via social media.Community Mental Health Journal, 56(5), 786-792. https://doi.org/10.1007/s10597020-00624-5

15. Cobham, V. E., McDermott, B., Haslam, D., \& Sanders, M. R. (2016). The role of parents, parenting and the family environment in children's post-disaster mental health. Current Psychiatry Reports, 18(6). https://doi.org/10.1007/s11920-016-0691-4

16. Daelo, E. (2010). Perceived Effects of Parents Disciplinary Actions on the Academic Performance of Grade Vi Pupils in Barra Elementary School, A.Y. 2009-2010. Lucban, Quezon:Southern Luzon State University.

17. Endendijk, J. J., Groeneveld, M. G., BakermansKranenburg, M. J., \& Mesman, J. (2016). Gender-differentiated parenting revisited: Metaanalysis reveals very few differences in parental control of boys and girls. PLoS ONE, 11(7), 1-33

18. Flannery, M. E. (2014, October 28). All in the family: How teacher home visits can lead to school transformation. Retrieved from http://neatoday.org/2014/10/28/all-in-the-familyhow-teacherhome-visits-can-lead-to-schooltransformation/
19. Froiland, J. M. (2015). Parents' weekly descriptions of autonomy supportive communication: Promoting children's motivation to learn and positive emotions. Journal of Child and Family Studies, 24, 117-126.

20. Griffith, A. K. (2020). Parental burnout and child maltreatment during the COVID-19 pandemic. Journal of Family Violence. https://doi.org/10.1007/s10896-020-00172-2

21. Gross (2015) "Relationship pf perceived parenting style, locus of control orientation and self-conceptAmong junior high age students". Fromhttp://dspace.library.colostate.edu/webclien t/DeliveryManager/digitool_items/csu01_storage /2014/09/09file_1/333763

22. Henderson Lora, J., Williams, Joanna, L., and Bradshaw, Catherine, P., (2020). Examining home-school dissonance as a barrier to parental involvement in middle school.

23. Higgins, Aria Zhalet (2011) "Psychological Effects on Academic Performance". Online Thesis and Dissertation Paper 21. http://encompass.eku.edu/etd/21

24. Hitting the streets for home visits. Leadership, 39(2), 24-26. The Effects of Teachers Home Visits on Student Behavior, Student Academic Achievement, and Parent Involvement Kim Wright, Samantha M. Shields, Katie Black, and Hersh C. Waxman

25. Hornby, Garry (2011). Parental Invovlement in Childhood Education. Springer Verlag, New York

26. Huang, J., Nigatu, Y. T., Smail-Crevier, R., Zhang, X., Wang, J. (2018). Interventions for common mental health problems among university and college students: A systematic review and meta-analysis of randomized controlled trials. Journal of Psychiatric Research, 107, 1-

10. https://doi.org/10.1016/j.jpsychires.2018.09.0 18

27. Ilhan, F. Ozfidan, Yilmas S., Home visit effectiveness on students' classroom behavior and academic achievement (2019). Journal of Social Studies Education.

28. Kazerooni, A., Amini, M., Tabari, P., Moosavi, M. (2020). Peer mentoring for medical students during the COVID-19 pandemic via a social media platform. Medical Education, 54(8), 762763. https://doi.org/10.1111/medu.14206

29. Khan, R., Bushra Igbal Chohan, (2011), Impact of Parental Support on the Academic Performance and Self Concept of the Student.

30. Lanciano Tiziana, Curci Antonietta. The Incremental Validity of Emotional Intelligence ability in Predicting Academic Achievement. https://doi.org/10.5406/amerjpsyc.127.4.0447

31. Landa, JMA , E. Lopez-Zafra, (2010). The impact of emotional intelligence on nursing: An overview. doi:10.4236/psych.2010.1008

32. Lin, M., \& Bates, A. B. (2010). Home visits: How do they affect teachers' beliefs about teaching and diversity? Early Childhood Education Journal, 38(3), 179-185 https://doi.org/10.1007/s10643-010-0393-1 
33. Liu, Cindy H., Amaker Stephanie Pinder, Hyeouk, Chris Ham, Chen, Justin (2020). Priorities for addressing the impact of the Covid-19 Pandemic on college student mental health. https://doi.org/10.1080/07448481.2020.1803882

34. Lucas, M. A. (2017). Bridging the gap between schools and families through teacher home visits (Unpublished doctoral dissertation). Lindenwood University, St. Charles, Missouri. Retrieved from https://search.proquest.com/openview/f391f0fd05 84 e52a816caeb63fle2e26/1 ? pqorigsite $=$ gschola $r \& c b l=18750 \&$ diss $=y$

35. Meyer, J. A., \& Mann, M. B. (2011). Teachers' perceptions of the benefits of home visits for early elementary children. Early Childhood Education Journal, 34(1), 93-97.

36. Minn, C. \& Hau, I. (2020, May 20). The next pandemic: Mental health. The EdSurge, https://www.edsurge.com/news/2020-0530thenextpandemic-mental-health.

37. Nyarko (2011) The Influence of Authoritative Parenting Style on Adolescents Academic Achievement.

38. OHCHR/DECLARATION ON THE RIGHT OF THE CHILD (1959) https://www.ohchr.org/EN/Issues/Education/Trai ning/Compilation/Pages/1DeclarationoftheRights oftheChild(1959).aspx

39. Orben, A., Tomova, L., Blakemore, S.-J. (2020). The effects of social deprivation on adolescent development and mental health. The Lancet Child and Adolescent Health 4(8), 634640.

40. Pajarianto, H., Abdul Kadir, Nursaqinah Galugu, Puspa Sari, Sofia Februanti (2020), Study from Home in the Middle of the COVID-19 Pandemic: Analysis of Religiosity, Teacher, and Parents.

41. Philippine Copyright 2005, Chanrobles Publishing Company

42. Premier Value Provider Inc as cited in one news ph (2020) Stress, Anxiety, Depression on the Rise Among Gen Z, Millennial Employees and Those Working from Home (Survey).

43. Rafiq, et. al., (2013). Parental Involvement and Academic Achievement; A Study on Secondary School Students of Lahore, Pakistan. International Journal of Humanities and social Science. Bolume 3 No.8 Special Issue-April 2013.

44. Rosales, Sj. (2014). Parenting Style and Its Development of Social Competence Among Grade III Pupils, A.Y. 2013-2014. Lucban, Quezon: Southern Luzon State University.

45. Ruholt, Jonathan, S., and Dukes, Kristina (2015). Is Parental Support or Parental Involvement More Important for Adolescents?

46. Soto, J. et al. (2015). Personality Traits in Childhood and Adolescence: Structure, Development, and Outcomes. https://doi.org/10.1177/0963721415589345

47. Smith, Krishna (2011). The Impact of Parental Involvement on Student Achievement. ProQuest LLC. United States.

48. St. Paul Federation of Teachers. (2014). Parent/teacher home visiting. Project evaluation. Retrieved from www.spft.org/wp- content/uploads/2013/08/spft-report-071014.pdf Stuht, A. C. (2009).

49. Teruel, David Sánchez, María Auxiliadora Robles-Bello, Nieves Valencia Naranjo (2020), Do psychological strengths protect college students confined by COVID-19 to emotional distress? The role of gender. https://doi.org/10.1016/j.paid.2020.110507

50. Thompson, R. A. (2012). Whither the preconventional child? Toward a life-span moral development theory. Child Development Perspectives, 6, 423-429.

51. Untevero, Aivie R. "Parental Involvement in Academic Performance of Selected Bachelor of Science in Nursing Level IV Students in SLSU. "Unpublished Thesis, College of Teacher Educational Lucban, Quezon. (2013).

52. Wilk, P. et al., (2018) Exploring the Effect of Parental Influence on Children's Physical Activity. The Mediating Role of Children's Perceptions of Parental Support. https://doi.org/10.1016/j.ypmed.2017.10.018.

53. Wright, Kim, B., Shields, Samantha, M., Black, Katie ans Waxman, Hersh, C., (2018). The Effects of Teacher Home Visits on Student Behavior, Student Academic Achievement, and Parent Involvement

54. Zhai, Y. and Xue D. (2020) Addressing collegiate mental health amid Covid-19 pandemic https://dx.doi.org/10.1016\%2Fj.psychres.2020.11 3003 